\title{
PHYTOTOXICITY AND FIELD EFFICACY OF EXSEROHILUM LONGIROSTRA JC/MIN THE CONTROL OF BARNYARDGRASS ECOTYPES (ECHINOCHLOA CRUS-GALLI VAR. CRUS-GALLI(L.) BEAUV)
}

\author{
ABDULSHUKORJURAIMI, ARIFINTASRIF, JUGAHKADIR*, SUHAIMINAPIS' \\ and SOETIKNO SLAMET SASTROUTOMO ${ }^{2}$
}

*Faculty of Agriculture, Universiti Putra Malaysia, 43400 Serdang, Malaysia

; 'Faculty of Biotechnology and Science ofBiomolecular, 43400 Serdang, Malaysia

CAB International SEA Regional Centre, 43400 Serdang, Malaysia;

\begin{abstract}
Five selected ecotypes of bamyardgrass (Echinochloa crus-galli var. crus-gatti) from several rice growing areas in Malaysia and Indonesia were tested for their susceptibility to the potential bioherbicide (Exserohilum longirostratum). Bamyardgrass seedlings at the 2-3-lcaf stage were treated with $2.5 \times 10^{7}$ conidia/ml from E. longirostratum at different application frequencies (single, double and triple). In addition, aqueous extract assays were evaluated for the presence of a phytotoxic compound responsible for the virulence of the bioherbicide. Results of the study showed that disease severity significantly increased 20 days after treatment and resulted in mortality of the seedlings. Ecotypes from Perak and Lampung were most susceptible to the bioherbicide upon triple applications. Percentage dry weight reductions were 86.34 and 83.14\%, respectively. Other ecotypes (Melaka, Banten and South Sulawesi) were observed to have a relatively similar response. Moreover, aqueous extracts of E. longirostratum increased mortality up to $92.50 \%$ of bamyardgrass seedlings. These findings suggest that regular (double and triple) applications of E. longirostratum at a concentration of $2.5 \times 10^{\gamma}$ conidia/ml significantly increased mortality among bamyardgrass ecotypes. Mortality of the seedlings was attributed to the presence of a secondary phytotoxic metabolite.
\end{abstract}

Key words : Field efficacy / Phytotoxicity / Exserohilum longirostratum I Echinochloa crus-galli var. crusgalli I ecotypes.

\section{INTRODUCTION}

Bamyardgrass (Echinochloa crus-galli var. crus-galli (L.) Beauv) is the most important weed occurring in rice (Holm et al. 1977). Although various management strategies are available for bamyardgrass control in rice (e.g., cultural measures, hand-weeding, mechanical control and herbicides), each has its limitations (Matsunaka 1983).

Following some recent successes in using plant pathogens as biological agents to control weeds (Charudattan 2000), the possibility of using the bioherbicide approach to control bamyardgrass in rice-based cropping systems was investigated in the Philippines and Japan (Zhang and Watson 1997; Tsukamotoe? al. 1999). As

\footnotetext{
*) Correspondent to : Jugah Kadir, Department of Plant Protection, Faculty of Agriculture, Universiti Putra Malaysia,
} 43400 Serdang, Selangor, Malaysia Email : kadirj2000@yahoo.com 
such Exserohilum monoceras has since been selected to be the potential biocontrol agent for Echinochloa species (Zhang et al. 1997; Tzukamoto et al. 1999). In addition, high virulence of $E$. monoceras on barnyardgrass species was due to the production of a phytotoxic compound by this fungus (Zhang and Watson 2000). Furthermore, another species, Exserohilum longirostratum was shown to be a potential biocontrol agent of itchgrass (Ahmad et al. 2002). The possibility of using Exserohilum longirostratum as a mycoherbicide to control barnyardgrass was investigated under glasshouse conditions. This fungus has also been recorded as a potential biocontrol agent for grassy weeds (Chandramohan and Charudattan 2001) and is mainly host specific to grassy weeds, while broadleaf weeds and crops are highly resistant (Kadir et al. 2003).

Previously, we reported that E. longirostratum suppressed the growth of barnyardgrass and significantly reduced above ground biomass when applied at $\mathrm{IxlO}^{7}$ conidia/ml under glasshouse conditions (Tasrif et al. 2003). Based on the glasshouse studies, we decided to examine the efficacy of this pathogen in field conditions and assess the possibility that a phytotoxin may be responsible for the virulence. Thus, the objective of this study was to quantify the efficacy of Exserohilum longirostratum in suppressing ecotypes of barnyardgrass at different frequencies of application and its phytotoxic effect on barnyardgrass seedlings.

\section{MATERIALS AND METHODS Seed sources and inoculum production}

The five selected ecotypes of barnyardgrass for field experiments were collected from Malaysian and Indonesian rice fields. The distance between sampling locations were within 5 to 10 km (Table 1).

Table 1. Selected ecotypes of barnyardgrass for field efficacy studies

\begin{tabular}{lll}
\hline Ecotype & Location & Region \\
\hline PK-04 & Perak & Malaysia \\
M-01 & Melaka & Malaysia \\
L-01 & Lampung & Indonesia \\
B-04 & Banten & Indonesia \\
SS-01 & South Sulawesi & Indonesia \\
\hline
\end{tabular}

Small pieces of mycelium from the stock culture were aseptically transferred to Potato Dextrose Agar (PDA) in petri dishes. Each PDA culture was sealed with parafilm and incubated at room temperature (approximately $+30^{\circ} \mathrm{C}$ ) for 7 days. Agar plugs with mycelium (6 mm diameter) from the margins of these young 
Phytotoxicity and field efficacy of Exserohilum longirostratum - Abdul Shukor Juraimi et al.

colonies were used as source of inoculum. V-8 juice (V-8 juice of $200 \mathrm{ml}$, agar $18 \mathrm{~g}$ and distilled water 1 liter) medium were used for inoculum production following tray-mass method. The inoculum of selected potential fungal pathogen was produced on V-8 juice agar added with 3.7 $\mathrm{mg} / 1$ of streptomycin sulfate and $2.5 \mathrm{mg} / 1$ of choloramphenicol. The antibiotic was added to prevent bacterial contamination. Approximately $50 \mathrm{ml}$ of mycelia suspension were sprayed on the food trays (size $20 \times 30 \mathrm{~cm}$ ) containing about $300 \mathrm{ml}$ of V-8 juice agar. Then the inoculated trays were incubated at room temperature $\left(25^{\circ} \mathrm{C}\right.$ to $\left.30^{\circ} \mathrm{C}\right)$ for 2 to 3 days under 12 hour light/12 hours dark cycle. Conidia were collected from a 2-day-old culture by scraping the agar surface with sterile water and rubber spatula, and filtering conidial suspension through a single sterile cheesecloth (Kadir and Charudattan 2000).

\section{Field Trials}

Field trials were conducted in Field 2 of the Faculty of Agriculture, Universiti Putra Malaysia. Plastic buckets (20cm diameter and $30 \mathrm{~cm}$ height) were filled each with $15 \mathrm{~kg}$ soil (Jawa series) from Tanjong Karang paddy fields. Each bucket was planted with pre-germinated seeds of barnyardgrass ecotypes. Basal fertilizer (45 kg N/ha, $40 \mathrm{~kg}$ P/ha and $30 \mathrm{~kg} \mathrm{~K} / \mathrm{ha}$ ) was applied before planting (Pane and Masshor 1997). One week after emergence, the 2-3-leaf stage seedlings were selected and thinned to 5 seedlings/bucket. An E. longirostratum concentration of $2.5 \times 10^{7}$ conidia/ml as counted using haemocytometer was used with $0.05 \%$ Tween 20 as wetting agent diluted in water. Each treatment was sprayed with $100 \mathrm{ml}$ conidial solution using hand sprayer. Tween 20 has been used in field trials as an additive to spore suspension to improve plant kill (Klein and Auld 1995). Disease assessment was determined at 5-day intervals for 20 days after spraying. Disease assessment was done visually based on a disease severity scale as developed by Kadir and Charudattan (2000).

The disease ratings were: 0: 0\% infection, 1: 1 to 10\% leaf area are damaged, 2: 11 to $20 \%$ leaf area are damaged, 3: 21 to 30\% leaf area are damaged, 4: 31 to 40\% leaf area are damaged, 5: 41 to 50\% leaf area are damaged, 6: 51 to 60\% leaf area are damaged, 7: 61 to 70\% leaf area are damaged, 8: 71 to $80 \%$ leaf area are damaged, 9: 81 to 90\% leaf area are damaged and 10: 91 to $100 \%$ leaf area are damaged (plant died). Environmental conditions such as relative humidity, rainfall and temperature during the study were noted. This was a factorial experiment in a randomized complete block design. Barnyardgrass ecotypes (PK-04, M-01, L-01, B-04 and SS01) were selected as factor one, while the frequency of applications (single, double and triple applications) was selected as the second factor. Each treatment combination was repeated four times. All control plants were sprayed with water containing $0.05 \%$ Tween 20 . A completely randomized design was carried out to determine the phytotoxic effect. 


\section{Phytotoxic effect of aqueous extracts}

Agar plugs (6 mm diameter) of the fungus taken from the edge of 7-day-old PDA cultures (inoculum) were placed into 500-ml Erlenmeyer flasks containing $100 \mathrm{ml}$ of modified Fries liquid medium (30.0 g of sucrose, $5.0 \mathrm{~g}$ of $\mathrm{KH}_{2} \mathrm{PO} 4,0.5 \mathrm{~g}$ of ammonium tartrate, $1.0 \mathrm{~g}$ of $\mathrm{MgSO}_{4}, 0.1 \mathrm{~g}$ of $\mathrm{NaCl}, 0.1 \mathrm{~g}$ of CaCla, $0.5 \mathrm{~g}$ of casein hydrolysate, and $1.0 \mathrm{~g}$ of yeast extract in $1000 \mathrm{ml}$ of distilled water) (Zhang et al. 1996). Flasks were then placed on rotary shakers at 100 "rpm" and flask containing only modified Fries medium served as control. After a 2-week incubation, cultures collected from each flask were separately centrifuged at 6000 "rpm" for $10 \mathrm{~min}$. The supernatant was filtered through cheesecloth, followed by two layers of Whatman No.2 filter paper to obtain a cell-free culture filtrate. The 3 concentrations of the $E$. longirostratum aqueous extract used were full-strength (v/v) (250 ml/1) half-strength $(125 \mathrm{ml} / 1)$ and quarter-strength $(62.5 \mathrm{ml} / 1)$. Dilutions were made with sterilized distilled water. The roots of the barnyardgrass seedlings at the 2-leaf growth stage were immersed in plastic containers containing $25 \mathrm{ml}$ of the aqueous extract. Observations were carried out 48 hours later. Disease severity was assessed based on disease incidence (percentage of diseased plant) (Kadir and Charudattan 2000). Necrosis and wilting indicated the presence of the phytotoxic compound in the aqueous extract.

\section{Statistical Analysis}

Anova was used to test for the determination of significant differences among treatment combinations, while mean separation was resolved using Duncan's New Multiple Range Test at $\mathrm{P}$ $<0.05$ (SAS 2000) for both experiments. Disease severity was determined according to area under disease progress curve (AUDPC) (Campbell and Madden 1990). The AUDPC is the disease intensity between two periods. The higher the AUDPC value, the more severe the disease is. Dry weight above ground biomass reduction (percent control) was taken 20 days after spraying. Disease assessments were carried out based on disease index scale (0: immune, 1-2: resistant, 3-4: tolerant, 5-7: susceptible and 8-10: highly susceptible) (Chang and Hwang 2003).

\section{RESULTS Field efficacy studies}

Means Relative Humidity (\%), temperature $\left({ }^{\circ} \mathrm{C}\right)$ and rainfall at the experimental sites were $94 \%, 24$ to $33^{\circ} \mathrm{C}$ and $8 \mathrm{~mm}$, respectively. Location of the trials had no significant effect on growth of barnyardgrass ecotypes.

The disease severity that was observed for all ecotypes tested as expressed by AUDPC ranged from 590 to 1118 units 20 days after spraying (Table 2). The results 
Phytotoxicity and ficld efficacy of Exserohilum longirostratum - Abdul Shukor Juraimi et al.

Table 2. Disease severity (AUDPC) among 2-3-leaf stage of barnyardgrass 20 days after treatments with $E$. longirostratum conidia.

\begin{tabular}{|c|c|c|c|}
\hline \multirow{2}{*}{ Ecotype } & \multicolumn{3}{|c|}{ Frequency of application } \\
\hline & Single & Double & Triple \\
\hline PK-04 & $814 \mathrm{aB}$ & $1024 \mathrm{aA}$ & $1118 \mathrm{aA}$ \\
\hline M-01 & $656 \mathrm{cbB}$ & $744 \mathrm{bcAB}$ & $775 \mathrm{cA}$ \\
\hline L-01 & $808 \mathrm{aB}$ & $993 \mathrm{aA}$ & $1083 \mathrm{aA}$ \\
\hline B-04 & $707 \mathrm{abB}$ & $826 \mathrm{cA}$ & $883 \mathrm{bB}$ \\
\hline SS-01 & $590 \mathrm{cB}$ & $706 \mathrm{cA}$ & $773 \mathrm{cA}$ \\
\hline
\end{tabular}

AUDPC-area under disease progress curve (Campbell and Madden 1990);

Column means followed by the same small letter and row means followed by the same capital letter arc not significantly different at the $5 \%$ level by Duncan's New Multiple Range Test (DNMRT).

indicate that the AUDPC for ecotype of PK-04 (1118) and L-01(1083) were more severely affected by treatment with E. longirostratum conidia than ecotypes M-01(775), B-04 (883), and SS-01(773). It is interesting to note that the effects of application frequencies for PK-04 and L-01 ecotypes were similar (Table 2).

Effects of application frequency on seedling response as shown by the AUDPC also were observed. Ecotypes PK-04 and L-01 gave similar responses for all spray frequencies and were significantly different $(\mathrm{P}<0.05)$ compared to other ecotypes. Ecotypes M-01 and SS01 gave similar responses at triple application frequencies. Ecotype of B-04 and SS-01 had similar response at double application frequencies.

The effect of application frequency on dry weight reduction of above ground biomass for all treatments is presented in Table 3. The range of dry weight reduction was 37.58 to 86.34\%. Ecotypes of PK-04 and L-01 yielded the highest dry weight reduction (86.34 and 83.14\%) at triple applications and was significantly different compared to other ecotypes. The least dry weight reduction was recorded for the SS-01 ecotype at all three levels of applications. The single and double application frequencies that reduced ecotypes biomass by more than 50\% were observed for the PK-04 and L-01 ecotypes. However, double and triple applications reduced dry weight biomass below 50\% for SS-01 ecotypes. In general, ecotypes PK-04 and L-01 were found to be most susceptible to. E. longirostratum injury.

At triple applications, PK-04 disease severity increased up to 15 days after spraying but leveled off afterwards. At a single application, the disease severity increased up to 10 days following applications then leveled off afterwards (Figure 1). However, at triple applications the level of disease severity increased beyond values obtained for those receiving double and single applications. 
Table 3. Dry weight reduction (percent control) among 2-3- leaf stage of barnyardgrass 20 days after treatment with $E$. longirostratum conidia.

\begin{tabular}{lccc}
\hline \multirow{2}{*}{ Ecotype } & \multicolumn{3}{c}{ Frequency of application } \\
\cline { 2 - 4 } & Single & Double & Triple \\
\hline PK-04 & $58.153 \mathrm{aB}$ & $63.247 \mathrm{aB}$ & $86.338 \mathrm{aA}$ \\
M-01 & $41.308 \mathrm{bcB}$ & $50.862 \mathrm{bAB}$ & $54.203 \mathrm{cA}$ \\
L-01 & $53.115 \mathrm{aC}$ & $70.620 \mathrm{aB}$ & $83.140 \mathrm{aA}$ \\
B-04 & $44.355 \mathrm{Bc}$ & $53.163 \mathrm{bB}$ & $61.908 \mathrm{bA}$ \\
SS-01 & $37.583 \mathrm{Cb}$ & $44.903 \mathrm{bA}$ & $49.903 \mathrm{cA}$ \\
\hline
\end{tabular}

Column means followed by the same small letter and row means followed by the same capital letter are not significantly different at the $5 \%$ level by Duncan's New Multiple Range Test (DNMRT).

\section{A. Perak ecotype (PK-04)}

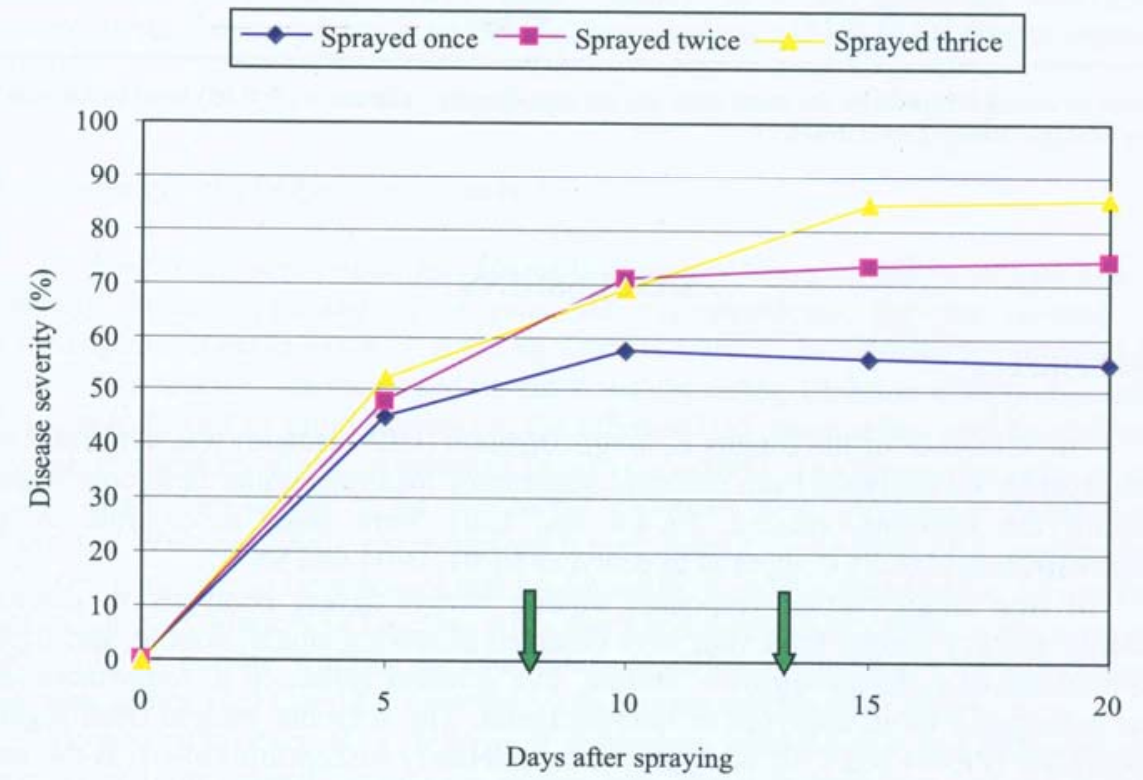

Figure 1. Disease severity (\%) of Exserohilum leaf blight on a highly susceptible ecotype (PK-04) caused by $E$. longirostratum. The arrows indicate the days when double and triple applications were administrated. 
Phytotoxicity and field efficacy of Exserohilum longirostratum — Abdul Shukor Juraimi et al.

\section{Phytotoxic effect of aqueous extracts}

Three aqueous extract concentrations at full, half, and quarter-strength prepared from the fungus produced necrotic, chlorosis and wilting in E. crus-galli seedlings within 48 hours after immersion. At full strength, the solution reduced living leaf area by a disease incidence of $92.5 \%$ as compared to controls and was significantly different compared to the other two treatments. Half strength and quarter strength aqueous extracts caused a disease incidence of $85.0 \%$ and $57.5 \%$, respectively (Table 4). The results indicated that higher aqueous extract concentration increased seedling mortality.

Table 4. Mean disease incidence of 2-leaf stage barnyardgrass seedlings 48 hours after immersion

\begin{tabular}{ll}
\hline \hline Aqueous extract concentration & Disease incidence (\%) \\
\hline Full-strength $\left(250 \mathrm{ml} \mathrm{L}^{-1}\right)$ & $92.50 \mathrm{a}$ \\
Half-strength $\left(125 \mathrm{ml} \mathrm{L}^{-1}\right)$ & $85.00 \mathrm{~b}$ \\
Quarter-strength $\left(62.25 \mathrm{ml} \mathrm{L}^{-1}\right)$ & $57.50 \mathrm{c}$ \\
\hline
\end{tabular}

Values of means followed by the same letter are not significantly different at $(\mathrm{P} \leq 0.05)$ level by Duncan's New Multiple Range Test (DNMRT).

\section{DISCUSSIONS}

\section{Field efficacy}

The virulence of the fungus E. longirostratum (UPM isolate) was evaluated on 5 barnyardgrass ecotypes from different geographic locations under field conditions. Among the ecotypes studied, PK-04 and L-01 were most susceptible to E. longirostratum toxicity compared to ecotypes M-01, B04 and SS-01.

In this study, varied responses among barnyardgrass ecotypes in disease severity and dry weight reduction were obtained following single, double, and triple applications of $E$. longirostratum conidia. The conidial isolate of E. longirostratum was pathogenic to all ecotypes of barnyardgrass. The response ranged from highly susceptible (PK-04 and L-01 ecotypes) and moderately susceptible (M-01, B-04, and SS-01 ecotypes) was recorded in our field experiments. Similar variability in pathogenic response among different ecotypes has also been reported for other plants. Leisner and Howel (1992) reported variation in symptoms from highly susceptible to resistant among 18 ecotypes of Arabidopsis thaliana infected by Cauliflower Mosaic Virus (CMV). In another study, Chang and Hwang (2003) reported significant differences in level of disease response among 6 Adlay cultivars to fungal Bipolaris coicis from different locations in South Korea. 
E. longirostratum reduced growth and dry weight of barnyardgrass ecotypes PK-04, L-01 and B-04. However, efficacy of this fungus to control barnyardgrass depends on conidial concentration, frequency of application, and the genetic variability of barnyardgrass ecotypes. Several publications on other fungal bioherbicides suggest an inoculum concentration of $10^{6}$ conidia/ml to be the effective concentration in their studies (Wymore and Watson 1989; Kadir et al. 2000). Rosskopt et a/.(1999) also observed that the optimal level of control over Amaranthus species by Phomopsis amaranticola occurred at $6 \mathrm{xl}^{7} \mathrm{conidia} / \mathrm{ml}$. Accordingly, we agreed on an inoculum density of $2.5 \times 10^{7}$ conidia/ml for E. longirostratum for our studies.

Regular application of certain bioherbicides has been reported to provide long-term control of the target weed. For example, Kadir and Charudattan (2000) reported that Dactylaria higginsi provided excellent long-term control of purple nutsedge (Cyperus rotundus L.) when it was applied regularly. In this study, regular application of E. longirostratum significantly controlled barnyardgrass. However, the severity of the disease caused by this fungus for barnyardgrass ecotypes in the field did not always correlate well with the aggressiveness observed in glasshouse studies. This may suggest that other factors such as increased inoculum concentration, improved formulation and barnyardgrass density influence disease severity.

\section{Phytotoxic effect of aqueous extracts}

E. longirostratum causes leaf blight in Echinochloa crus-galli ecotypes and is presently being evaluated as a potential mycoherbicide for the control of barnyardgrass. Inoculation with aqueous extracts from $E$. longirostratum resulted in a blight-like reaction characterized by chlorosis appearing 12 hours after immersion. This was followed by rapid necrosis of the affected leaf tissue, often with an absence or weak expression of typical lesions (Tasrif et al. 2003). The symptoms induced by $E$. longirostratum appear to be due to the presence of a phytotoxic compound. Zhang and Watson (2000) characterized the phytotoxic compound of E. monoceras as Toxin-1, shown to be a potent and host-specific principle responsible to disease expression in Echinochloa species. Also, the toxin tryptophol appear to be a major metabolite in culture filtrates of Drecshlera nodulosa, a pathogen of goosegrass (Eleusine indica (L.) Gaerth.) reported by Sugawara and Strobel (1987).

Microscopic observation following treatments with the full and half-strength aqueous extracts caused plasma-membrane breakdown in leaf tissue of the highly susceptible ecotype PK04. These results would support the presence of a phytotoxin in the aqueous extracts, that may have affected plasma membrane integrity of susceptible ecotypes in the infection process of the fungus E. longirostratum. Ismail et al. (1993) have reported similar results from full-strength of aqueous extracts of legume cover crops that decreased germination and seedling growth of Asystasia intrusa and Paspalum conjugatum weeds attributed to an allelopathic principle. 
Phytotoxicity and field efficacy of Exserohilum longirostratum - Abdul Shukor Juraimi et al.

In this study, our results demonstrate that E. longirostratum at a concentration of $2.5 \times 10^{7}$ conidia/ml effectively increased the mortality of barnyardgrass ecotypes at the 2-3-leaf stage.

\section{CONCLUSIONS}

The fungal pathogen E. longirostratum seems to be a potential candidate as mycoherbicide on barnyardgrass. Phytotoxic compound of this fungus might also enhance virulence on barnyardgrass. However, for satisfactory control on barnyardgrass, further studies need to be addressed on the increase in conidial concentration, use of different surfactant, formulation, and time of application.

\section{ACKNOWLEDGEMENT}

Our appreciation goes to the Integrated Pest Management for Small-Estate Crop Project (IPM-SCHEP), Ministry of Agriculture in Indonesia and Felda Foundation of Malaysia who had funded this study. We also thank Ms. Christina Stephensons for her valuable contribution in correcting the manuscript.

\section{REFERENCES}

Ahmad, A., J. Kadir, M. Sariah, A.S. Juraimi, 2002. Evaluation for Drechslera sp. for potential bioherbicidc control of itchgrass (Rottboellia cochinchinesis; Poaccac). Screening and host range test. Proceedings Third International Conference on Biopesticidcs, ed. E.M. Mulla, The Department of Entomology, University of California, Riverside, USA. p. $181-184$.

Campbell, C.L. and L.V. Madden, 1990. Introduction to plant disease epidemiology. John Wilcy \& Son. 532 p.

Chandramohan, S. and R. Charudattan, 2001. Control of seven grasses with a mixture of three fungal pathogens with restricted host range. Biological Control, 22: 246-255.

Chang, S.W. and B.K. Hwang, 2003. Evaluation of virulence to adlays of Korean isolates of Bipolaris colds using a disease rating scale. Plant Disease, 726-731.

Charudattan, R. 2000. Current status of biological control of weeds: In Emerging technologies for integrated pest management. Concepts, research and Implementation, cds C.G. Kennedy and T.B. Sutton, St. Paul Minnesotta, APS Press, p.269-288.

Holm, L.G., D.L. Plucknett, J.V. Pancho and J.P. Herberger, 1977. The World's Worst Weeds. Distribution and Biology. Hawaii, Honolulu.

Ismail, B. S., A. Tasrif, Sastroutomo, S.S. and A. Latif, 1993. Allelopathic potential of legume cover crops on selected weed species. Plant protection quarterly, 86: 81-87.

Kadir, J. B. and R. Charudattan, 2000. Dactylaria higginsi, a fungal bioherbicide agent for purple nutsedge (Cyperus rotundas), Biological Control, 17: 113-124. 
Kadir, J., R. Charudattan and R.D. Berger, 2000. Effects of some epidemiological factors on levels of disease caused by Dactylaria higginsi on Cyperus rotundus. Weed Science, 48:61-68.

Kadir, J., A. Ahmad, M. Sariah and A.S. Juraimi, 2003. Potential of Drechslera longirostrata as bioherbicide for itchgrass (Rottboellia cochinchinensis). Proceedings of the Nineteenth Asian Pacific Weed Science Society Conference. Weed Science Society of the Philippines, Manila, Philippines, p 450-455.

Klein, T. A. and B.A. Auld, 1995. Evolution of twccn 20 and glycerol as additives to mycoherbicides suspensions applied to Bath rust burr. Plant Protection Quarterly, 1: 14-16.

Lcisner, S.M. S.H. Howell, 1992. Symptoms variation in different Arabidopsis thaliana ecotypes produced by cauliflower mosaic virus. Phytopathology, 82: 1042-1045.

Matsunaka, S. 1983. Evolution of rice weeds control practices and research: world perspective in weed control in rice. International Rice Research Institute. Manila, Philippines, p 5-17.

Pane, H. and M. Masshor, 1997. Fenoxaprop-P-ethyl is an effective herbicide in controlling red sprangletop (Leptochloa chinensis L. ness). Proceedings $16^{\mathrm{lb}}$ Asian Pacific weed Science Society Conference, -Malaysian Plant Protection Society, ed. Rajan, A. Kuala Lumpur, Malaysia.p.272-277.

Rosskofpf, E.N., R. Charudattan and J.B. Kadir, 1999. Use of plant pathogens in weed control In handbook of Biological control, eds. T.S. Bellows, T.W. Fisher, L.E. Caltagirone, D.L. Dahlsten, G. Gordt and C.B. Huffaker, San Diego, San Fransisco, New York, Boston, Sydney, Tokyo. Academic Press, p.891-919.

(SAS) Statistical analysis systems, 2000. SAS procedures guide version $8.03^{\text {rd }}$ Cory, NC: Statistical analysis systems.

Sugawara, F. and G.A. Strobel, 1987. Tryptophol, a phytotoxin produced by Drechslera nodulosum. Phytochemistry 26: 1349-1351.

Tasrif, A., A.S. Juraimi, J. Kadir, S. Napis and S.S. Sastroutomo, 2003. Mode of infection of Exserohilum longirostratum on barnyardgrass (E. crus-galli vat. crus-galli). 11* National electron microscopy conference, Langkawi 15-17 December 2003. p. $522-528$.

Tsukamoto, H., M. Tsuda, T. Fujimori, 1999. Mode of infection of Echinochloa oryzicola by Exserohilum monoceras. Phytopathology Sos. Japan, 65: 553-556.

Wymore, L. A. and A.K. Watson, 1989. Interaction between velvet leaf isolate of Colletotrichum cocodes and thidiazuron for velvet leaf (Abutilon theophrasti) in the field. Weed Science 37: 478-483.

Zhang, W.M., K. Moody and A.K. Watson, 1996. Responses of Echinochloa species and rice (Oryza saliva) to indigenous pathogenic fungi. Plant Disease 80: 1053-1058.

Zhang, W.M. and A.K Watson, 1997. Host range of Exserohilum monoceras, a potential bioherbicide for the control of Echinochloa species. Canadian Journal Botany, 75: 685-692.

Zhang, W.M. and A.K . Watson, 2000. isolation and partial characterization of phytotoxin produced by Exserohilum monoceras, a potential bioherbicide for control of Echinochloa species. Proceedings of the tenth International Symposium on Biological Control of Weeds, ed. N.R. Spencer, Montana, USA. p.125-130. 